\title{
Analisis Penyerapan Tenaga Kerja Wanita Pada Industri Kreatif di Sumatera Barat
}

\author{
Widya Fitriana ${ }^{1}$ \\ 1) Program Studi Agribisnis Fakultas Pertanian Universitas Andalas \\ Jl. Limau Manis Padang \\ Email: widyafitriana@agr.unand.ac.id
}

\begin{abstract}
ABSTRAK
Penelitian ini bertujuan untuk: (1) mendeskripsikan karaktersitik industri kreatif di Sumatera Barat, dan (2) menganalis faktor-faktor yang mempengaruhi serapan tenaga kerja wanita dalam pengembangan industri kreatif di Sumatera Barat. Kemampuan serapan tenaga kerja wanita (promoting gender balance) dihubungkan dengan karakteristik kewirausahaan, karakteristik usaha dan karakteristik wilayah. Penelitian ini menggunakan data survei industri mikro kecil (SIMK) 2014. Metode pengujian hipotesis dalam penelitian ini menggunakan analisis deskriptif dan analisis regresi linear berganda. Hasil penelitian menunjukkan bahwa karakteristik pengusaha (gender dan partnership), karakteristik usaha (asset dan sub sektor) serta karakteristik wilayah (GDP/capita) memiliki pengaruh dan signifikan secara statistik terhadap serapan tenaga kerja wanita pada industi kreatif di Sumatera Barat. Pemerintah sebaiknya melakukan upaya pemberdayaan tenaga kerja wanita melalui penguatan aspek usaha, kewirausahaan dan kewilayahan khususnya untuk mewujudkan pembangunan industri kreatif secara inklusif.
\end{abstract}

Kata kunci: Industri Kreatif, Tenaga Kerja Wanita, Pembangunan Inklusif

\begin{abstract}
This study aims to (1) describe the characteristics of the creative industry in West Sumatra, and (2) analyze the factors that influence the absorption of female labor in the development of creative industries in West Sumatra. The ability to absorb female labor (promoting gender balance) is associated with entrepreneurial characteristics, business characteristics and regional characteristics. This study uses survey data for the micro and small industry 2014. The method of testing the hypothesis in this study uses descriptive analysis and multiple linear regression analysis. The results showed that the characteristics of entrepreneurs (gender and partnership), business characteristics (assets and subsectors) and regional characteristics (GDP/capita) had a statistically significant and significant influence on the absorption of female labor in creative industries in West Sumatra. The government should make efforts to empower female workers through strengthening aspects of business, entrepreneurship and territoriality, especially to realize inclusive creative industrial development.
\end{abstract}

Keywords: creative industries, female labor, inclusive development 


\section{Pendahuluan}

Industri kreatif mulai menjadi perhatian para praktisi dan akademisi sejak ditemukannya fakta bahwa pada tahun 1996 ekspor hak cipta Amerika Serikat mempunyai nilai penjualan yang jauh melampaui nilai eksport sektor otomotif, pertanian dan pesawat. Howkins (2001) menyebut fenomena ini sebagai pencetus lahirnya gelombang ekonomi baru yakni ekonomi kreatif yang mengandalkan individual creativity, skill dan talent sebagai faktor utamanya. Kemunculan industri kreatif di era globalisasi juga tidak terlepas dari perubahan yang signifikan dari kemajuan tekhnologi informasi dan komunikasi (Sung, 2015)

Meskipun industri kreatif bermula di negara maju dengan dukungan perkembangan tekhnologi yang tinggi, bukan berarti konsep perkembangan industri kreatif tidak meluas ke negara-negara berkembang yang secara karakteristik jauh berbeda dengan negara maju baik dalam hal kualitas sumberdaya manusianya, daya tarik investasi, kondisi infrastruktur maupun kemajuan teknologi informasi dan komunikasi. Di Indonesia pengembangan industri kreatif tidak hanya terjadi di kota-kota besar di Pulau Jawa melainkan juga meluas ke kota-kota kecil di luar Pulau Jawa, salah satunya adalah di Provinsi Sumatera Barat. Sumatera Barat dikenal sebagai salah satu provinsi di Pulau Sumatera yang memiliki daya tarik investasi yang relatif rendah dibandingkan provinsi tetangganya yakni Riau dan Sumatera Utara namun mampu mencapai pertumbuhan ekonomi diatas rata-rata pertumbuhan ekonomi nasional. Hal ini salah satunya disebabkan oleh kekuatan ekonomi lokal yang bertumpu pada sektor usaha kecil yang tidak memiliki ketergantungn yang besar pada bahanbaku impor sehingga dapat menopang ekonomi Sumatera Barat terutama disaat krisis ekonomi. Menurut data BPS (2016) hampir 90\% industri manufaktur di Sumatera Barat merupakan usaha mikro dan kecil dan memiliki kontribusi serapan tenaga kerja hingga $6.86 \%$.

Sumatera Barat memiliki kekayaan socio cultural yang khas yang menjadikannya memiliki posisi yang kuat dalam menciptakan local branding. Saat ini pengembangan industri kreatif di Sumatera Barat didorong oleh nilai-nilai bermuatan spesifik kultural yang menonjolkan sub sektor kuliner, kriya dan fashion sebagai sektor andalan. Keberadaan industri kreatif diduga sangat berkaitan erat dengan penyerapan tenaga kerja wanita sebagai indikator untuk mengukur inklusi sosial. Menurut Cherayi dan Jose (2016) atribut penting dalam inklusi social adalah pemebrdayaan terutama pemberdayaan terhadap kelompok marginal dan promoting gender balance. Menurut Davys dan Tickle (2008) inklusi sosial terkait dengan konsep équal opportunities yakni memberikan kesempatan yang sama pada setiap individu yang hidup bersama dalam sebuah komunitas sosial tanpa membedakan etnis, gender dan ras. Cunningham (2002) menambahkan bahwa creatif industri dapat berperan dalam mempromosikan warisan dan keragaman budaya dan memperkuat inklusi social.

Adapun beberapa penelitian terdahulu yang mengkaji tentang inklusi sosial khususnya yang terkait dengan penyerapan tenaga kerja wanita adalah Pierson (2010), Flew (2013), Fletschner dan Carter (2008), Chaerayi dan Jose (2016), dan Fahmi et al (2017). Hasil penelitian tersebut menunjukkan bahwa inklusi sosial dipengaruhi oleh beberapa variabel antara lain karaktersitik pengusaha dan karakteristik perusahaan. Masih sedikit penelitian yang mengkaji pengaruh karakteristik wilayah terhadap inklusi sosial, padahal menurut Clare (2013) (2007) dan Orcao, et al (2018) ekslusi sosial bisa terjadi karena kondisi geografis yang tidak menguntungkan. Selain itu Handy dan Kassam (2006) juga 
mengungkapkan bahwa inklusi sosial juga bisa dipengaruhi oleh faktor ekonomi dan sosio kultural setempat. Untuk itu perlu penelitian lebih lanjut untuk melihat pengaruh dari ketiga aspek tersebut terhadap inklusi sosial khususnya terhadap pemberdayaan tenaga kerja wanita dalam pengembangan industri kreatif. Pengembangan industri kreatif secara esensial sangat sesuai dengan konsep pembangunan inklusif karena lebih mengedepankan kreatifitas sumberdaya manusia ketimbangan supremasi industri yang capital intensive. Disamping itu sejumlah riset yang mengkaji tentang pengembangan industri kreatif di Indonesia lebih banyak dilakukan pada kota-kota besar yang high income, memiliki daya tarik infestasi yang tinggi dan fasilitas infrastruktur yang memadai seperti di Kota Bandung (Simatupang et al, 2008), Jakarta (Sudarwati dan Prasetyawati, 2015) dan Bali (Widiastiti dkk, 2012). Penelitian ini mencoba memberikan kontibusi untuk mengisi research gap khususya pengembangan industri kreatif di kota-kota kecil/sedang yang bersifat low-middle income, daya tarik infestasi relatif rendah dan fasilitas infrastruktur yang kurang memadai. Hal ini dimaksudkan untuk memberikan peluang bagi daerah lain khususnya Sumatera Barat dalam pengembangan industri kreatif guna memacu pertumbuhan ekonomi daerahnya.

Berdasarkan latar belakang dan hasil penelitiah terdahulu maka tujuan dari penelitian ini adalah untuk: (1) Mendeskripsikan karaktersitik industri kreatif di Sumatera Barat, dan (2) Menganalisis pengaruh karakteristik kewirausahaan, karakteristik perusahaan dan karakteristik wilayah terhadap inklusi sosial terkait kemampuan industri kreatif dalam menyerap tenagakerja wanita. Perbedaan penelitian ini dengan penelitian sebelumnya terletak pada penambahan variabel pengamatan yakni karakteristik wilayah dalam mengukur inklusi sosial. Penelitian yang mengkaji tentang inklusi sosial pada industri mikro kecil di Indonesia sudah cukup banyak dilakukan Haslindah (2011), Sumantri (2013), dan Dasaluti, (2009) namun kajian inklusi sosial pada industri kreatif masih sangat terbatas. Pemilihan sampel industri kreatif yang dianalisis dalam penelitian ini mengacu pada Perpres No 72 Tahun 2015 tentang klasifikasi industri kreatif menurut KBLI (Klasifikasi Baku lapangan Usaha Indonesia) 5 digit.

Penelitian yang dilakukan oleh Henderson dan Williams (2013) menunjukkan bahwa tingkat pendidikan mempengaruhi inklusi sosial dimana orang yang berpendidikan rendah cenderung tidak mampu berpartisipasi melakukan pertukaran sosial dalam pasar tenaga kerja. Menurut Pierson, (2010) rendahnya keterampilan individu untuk mengakses pasar tenaga kerja juga dipengaruhi oleh hard skill dan soft skill yang dimilikinya. Secara umum perempuan dianggap lebih rentan mengalami ekslusi sosial dalam pasar tenaga kerja karena stigma sosial bahwa perempuan bersifat powerlessness dan lebih dibutuhkan bekerja untuk sektor domestik di rumah tangga dibandingkan masuk dalam pasar tenaga kerja dan berkompetisi dengan tenaga kerja laki-laki. Berdasarkan sejumlah penelitian diatas maka hipotesis yang dibangun dalam penelitian ini adalah:

H1: karakteristik pengusaha (tingkat pendidikan, umur, jenis kelamin, skill, dan kemitraan) berpengaruh terhadap inklusi sosial.

Penelitian yang dilakukan oleh Fami et al (2017) pada sejumlah industri kreatif di Indonesia mengungkapkan bahwa industri kreatif yang bersifat kultural lebih banyak membutuhkan tenaga kerja wanita daripada industri kreatif yang bermuatan tekhnologi modern. Sub sektor yang aktivitas utamanya mayoritas dikerjakan dengan tangan (done by hand) dan bersifat manual, cendrung lebih banyak membutuhkan tenaga kerja wanita daripada tenaga kerja pria seperti sub sektor kriya, fashion dan kuliner. Menurut Carter dan 
Smith (2016) penggunaan tenaga kerja wanita lebih banyak diserap oleh industri skala kecil dan pengalaman berusaha (business experience) yang masih baru ketimbang industri yang sudah mapan (mature). Perusahaan yang belum berbadan hukum (legality) juga cenderung menggunakan tenaga kerja wanita dengan proses rekrutmen yang lebih mudah berdasarkan relasi sosial yang dimiliki. Disamping itu, menurut Phuangrod et al (2017) orientasi pasar juga berpengaruh terhadap serapan tenaga kerja, perusahaan yang memiliki orientasi pasar yang luas dan sangat kompetitif akan lebih selektif dalam merekrut tenaga kerja yang sesuai dengan kebutuhan perusahaan terutama dalam hal melakukan inovasi. Berdasarkan sejumlah penelitian diatas maka hipotesis yang dibangun dalam penelitian ini adalah:

H2: karakteristik usaha (sub sektor, pengalaman berusaha, skala usaha, legalitas usaha, aset dan orientasi pasar eskport) berpengaruh terhadap inklusi sosial

Karakteristik geografis menurut hasil penelitian Clare (2013) dan Orcao et al (2018) merupakan salah satu faktor yang kondusif mendorong lahirnya ekslusi sosial karena masyarakat yang tinggal di tempat-tempat yang terisolasi, minim infrastruktur transportasi dan komunikasi, cenderung mengalami eksklusi sosial. Orang atau kelompok masyarakat ini tidak dapat berpartisipasi dalam pasar tenaga kerja yang lebih luas. Sebaliknya daerah yang memiliki ketersediaan infratrsutur, lifestyle dan quality of life yang baik dapat mendorong terwujudnya inklusi sosial. Hal ini sesuai dengan hasil penelitian Granger dan Hamilton (2010) bahwa daerah yang makmur dengan tingkat kemiskinan yang rendah serta memiliki infrastruktur yang baik terutama infrastruktur tekhnologi dan informasi merupakan faktor pendorong untuk mewujudkan pertumbuhan industri kreatif yang inklusif. Mengaju pada sejumlah penelitian diatas maka hipotesis yang dibangun dalam penelitian ini adalah:

H3: karakteristik wilayah (lokasi, pendapata/kapita, Indeks Pembangunan Manusia (IPM), rasio gini dan penggunaan internet) berpengaruh terhadap inklusi sosial.

\section{Metode Penelitian}

Penelitian ini dilakukan di Sumatera Barat yakni pada usaha/perusahaan industri manufaktur mikro dan kecil yang terdapat di 19 kabupaten/kota di Sumatera Barat. Penelitian ini dirancang untuk mengetahui pengaruh karakterisitk kewirausahaan, karakteristik perusahaan dan karakteristik wilayah terhadap inklusi sosial terkait kemampuan industri kreatif dalam menyerap tenaga kerja wanita. Objek penelitian ini adalah industri manufaktur berskala mikro kecil yang termasuk dalam klasifikasi industri kreatif menurut Peraturan Presiden Republik Indonesia No 72 Tahun 2015.

Rasio penggunaan tenaga kerja wanita dalam struktur tenaga kerja industri kreatif menjadi variabel terikat yang diukur dalam penelitian ini. Karaktersitik pengusaha, perusahaan dan wilayah menjadi variabel bebas. Karakterisitk kewirausahaan dilihat dari aspek pendidikan, umur, jenis kelamin, training, parthnership dan network. Karaktersitik perusahaan dilihat dari aspek skala usaha, pengalaman usaha, legalitas usaha, aset, sub sektor usaha, dan orientasi pasar. Karakteristik wilayah dilihat dari aspek lokasi, rasio gini, pendapatan perkapita, IPM dan penggunaan internet.

Data dalam penelitian merupakan data sekunder dengan menggunakan data mikro hasil Survey industri mikro kecil (SIMK) 2014 dari Badan Pusat Statistik (BPS). Dari data 
SIMK 2014 untuk Provinsi Sumatera Barat mensurvey 1'799 unit usaha/perusahaan. Data tersebut kemudian dipilah berdasarkan klasifikasi industri kreatif menurut Peraturan Presiden Republik Indonesia No 72 Tahun 2015 sehingga didapatkan 1.367 industri kreatif yang tersebar dalam 3 sub sektor usaha yakni: (1) kulier sebanyak 495 perusahaan (36,21\%), (2) kriya sebanyak 547 perusahaan (40,01\%), dan (3) fashion sebanyak 325 perusahaan $(23,77 \%)$.

Variabel terikat dalam penelitian diukur dari nilai proporsi kerja wanita yang digunakan dalam industri kreatif. Variabel bebas terdiri dari karakteristik kewirausahaan, karaktersitik perusahaan dan karakterisitk wilayah. Adapun defenisi operasional dan pengukuran variabel dijelaskan pada Tabel.1

Tabel 1. Variabel Penelitian dan Pengukurannya

\begin{tabular}{|c|c|c|c|}
\hline Variabel & $\underset{\mathbf{r}}{\text { Indikato }}$ & Label & Keterangan \\
\hline \multirow{8}{*}{$\begin{array}{l}\text { Karkatersitik } \\
\text { Pengusaha }\end{array}$} & Usia & AGE & Diukur dalam tahun \\
\hline & $\begin{array}{l}\text { Jenis } \\
\text { kelamin }\end{array}$ & GENDER & $\begin{array}{l}\text { Dummy variable } \\
\text { 1=jika pengusaha berjenis }\end{array}$ \\
\hline & Pendidikan & EDU & $\begin{array}{l}\text { Diukur dari lamanya pendidikan } \\
\text { formal yang ditamatkan (tahun) }\end{array}$ \\
\hline & $\begin{array}{l}\text { High } \\
\text { educated }\end{array}$ & $\begin{array}{l}\text { HIGH } \\
\text { EDU }\end{array}$ & $\begin{array}{l}\text { Dummy variabel: } 1=\text { jika } \\
\text { pengusaha lulusan diploma - } \\
\text { strata II, } 0=\text { lainnya }\end{array}$ \\
\hline & Kemitraan & COLL & $\begin{array}{l}\text { Dummy variabel; } 1=\text { jika } \\
\text { pengusaha pernah melakukan } \\
\text { kemitraan dengan pihak lain;0 } \\
\text { lainnya }\end{array}$ \\
\hline & Training & SKILL & $\begin{array}{l}\text { Dummy variable; } 1=\text { jika } \\
\text { pengusaha pernah mendapatkan } \\
\text { training atau penyuluhan dari } \\
\text { pihak lain;0 lainnya }\end{array}$ \\
\hline & Network & $\begin{array}{l}\text { NETWOR } \\
\text { K }\end{array}$ & $\begin{array}{l}\text { Dummy variabel: } 1=\text { jika } \\
\text { pengusaha terlibat dalam asosiasi } \\
\text { usaha selama } 1 \text { tahun terakhir, } \\
\text { 0=lainnya }\end{array}$ \\
\hline & $\begin{array}{l}\text { Usia } \\
\text { Produktif }\end{array}$ & ACTIVE & $\begin{array}{l}\text { Dummy variabel: } 1=\text { jika } \\
\text { pengusaha berada dalam rentang } \\
\text { usia sangat produktif yakni } 15-49 \\
\text { tahun, } 0=\text { lainnya }\end{array}$ \\
\hline \multirow[t]{2}{*}{$\begin{array}{l}\text { Karakteristik } \\
\text { usaha }\end{array}$} & sub sector & SECTOR & $\begin{array}{l}\text { Kegiatan utama dalam sub sektor } \\
\text { industri kreatif dimana }=1 \\
\text { kuliner, } 2=\text { kriya dan } 3=\text { fashion }\end{array}$ \\
\hline & $\begin{array}{l}\text { Business } \\
\text { experiance }\end{array}$ & BEX & $\begin{array}{l}\text { Diukur dalam lamanya } \\
\text { perusahaan beroperasi secara } \\
\text { komersil (tahun) }\end{array}$ \\
\hline
\end{tabular}




\begin{tabular}{|c|c|c|c|}
\hline & Skala usaha & SIZE & $\begin{array}{l}\text { Dummy vaiabel; diukur } \\
\text { berdasarkan skala usaha. } \\
\text { 1=industri kecil; } 0 \text { industri rumah } \\
\text { tangga }\end{array}$ \\
\hline & Legality & LEGAL & $\begin{array}{l}\text { Dummy variabel; } 1=\text { usaha telah } \\
\text { berbadan hukum; } 0=\text { lainnya }\end{array}$ \\
\hline & $\begin{array}{l}\text { Market } \\
\text { orientation }\end{array}$ & EXSPORT & $\begin{array}{l}\text { Dihitung berdasarkan share } \\
\text { penjualan untuk pasar luar negeri } \\
\text { (eksport) }\end{array}$ \\
\hline & Aset & ASET & $\begin{array}{l}\text { Dihitung berdasarkan nilai asset } \\
\text { usaha }\end{array}$ \\
\hline \multirow[t]{5}{*}{$\begin{array}{l}\text { Karakterisitik } \\
\text { wilayah }\end{array}$} & Location & LOC & $\begin{array}{l}\text { Dummy variabel: } 1=\text { bila } \\
\text { perusahaan berlokasi di daerah } \\
\text { perkotaan, } 0=\text { lainnya }\end{array}$ \\
\hline & GDP/capita & GDP & $\begin{array}{l}\text { Dikur berdasarkan nilai } \\
\text { GDP/capita di kabupaten/kota } \\
\text { lokasi perusahaan }\end{array}$ \\
\hline & Gini ratio & GINI & $\begin{array}{l}\text { Diukur berdasarkan nilai gini } \\
\text { ratio di kabupaten/kota lokasi } \\
\text { perusahaan }\end{array}$ \\
\hline & $\begin{array}{l}\text { Human } \\
\text { Development } \\
\text { Indeks }\end{array}$ & HDI & $\begin{array}{l}\text { Diukur berdasarkan nilai HDI di } \\
\text { kabupaten/kota lokasi perusahaan }\end{array}$ \\
\hline & Internet & NET & $\begin{array}{l}\text { Diukur berdasarkan nilai } \\
\text { persentase penduduk usia } 5 \text { tahun } \\
\text { keatas yang mengakses internet } \\
\text { di kabupaten/kota lokasi } \\
\text { perusahaan }\end{array}$ \\
\hline
\end{tabular}

Analisis data dilakukan dengan menggunakan analisis regresi linear berganda dengan menggunakan software STATA.14. Persamaan regresi linear berganda yang digunakan dalam penelitian ini adalah:

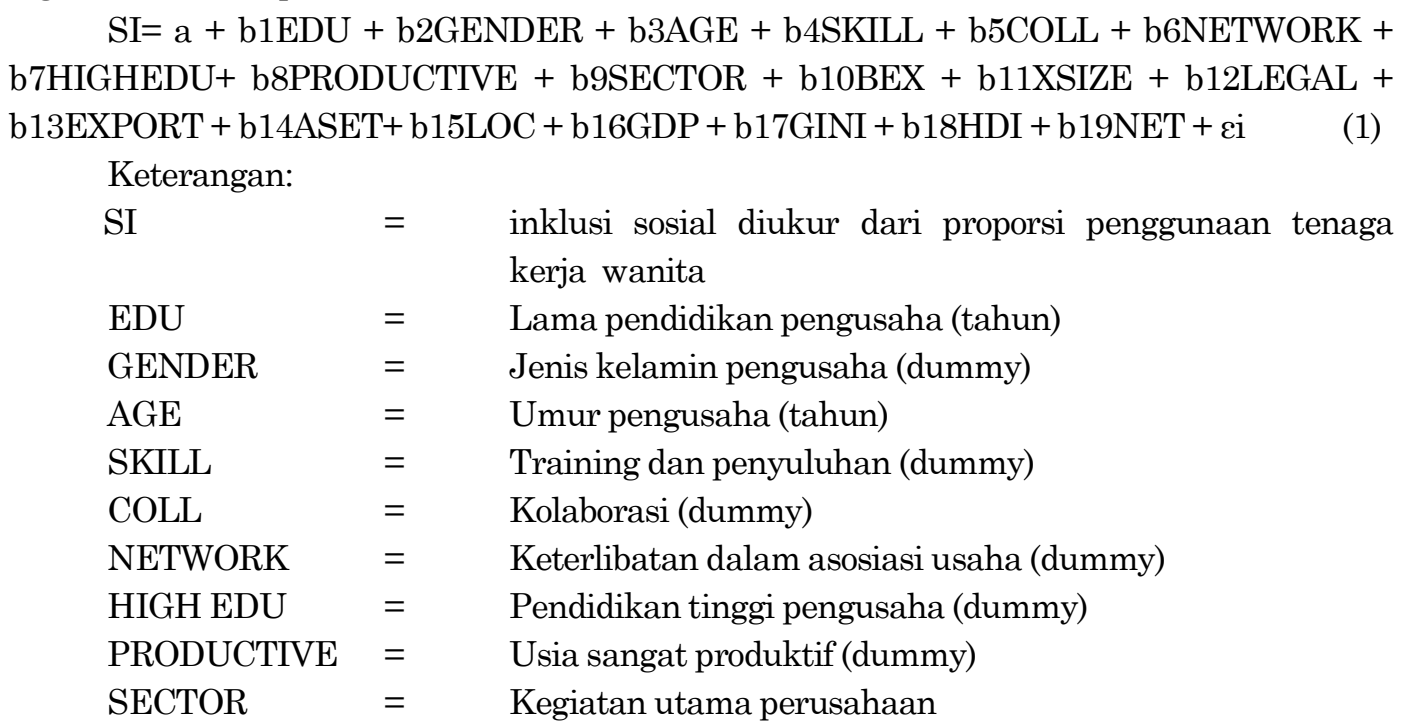




$\begin{array}{lll}\text { BEX } & = & \text { Pengalaman usaha (tahun) } \\ \text { SIZE } & = & \text { Skala perusahaan (dummy) } \\ \text { LEGAL } & = & \text { Status hukum perusahaan (dummy) } \\ \text { EXPORT } & = & \text { Share pasar eksport perusahaan (persentase) } \\ \text { ASET } & = & \text { Nilai asset perusahaan (ln) } \\ \text { LOC } & = & \text { Lokasi perusahaan (dummy) } \\ \text { GDP } & = & \text { GDP/capita (ratio) } \\ \text { GINI } & = & \text { Gini (ratio) } \\ \text { HDI } & = & \text { Indeks pembangunan manusia } \\ \text { NET } & = & \text { Akses internet (persentase) } \\ \text { A } & = & \text { Bilangan konstanta (intercept) } \\ \text { B } & = & \text { Koefisien regresi } \\ \text { ci } & = & \text { Residual error }\end{array}$

\section{Hasil dan Pembahasan}

Berdasarkan hasil pengelohan data SIMK 2014, dari 1.799 industri manufaktur yang ada di Sumatera Barat, didapatkan 1.367 industri yang tergolong sebagai industri kreatif berdasarkan Peraturan Presiden Republik Indonesia No 72 Tahun 2015. Jumlah industri kreatif terbesar adalah pada sub sektor kriya yakni 547 (40,01\%) perusahaan. Sebaran industri kreatif di Sumatera Barat untuk tiap-tiap sub sektor dijelaskan pada Tabel 2.

Tabel 2. Sebaran Industri Kreatif di Sumatera Barat Berdasarkan Sub Sektor

\begin{tabular}{|c|c|c|c|c|}
\hline $\begin{array}{c}\text { Sub } \\
\text { Sektor }\end{array}$ & Jumlah & \multicolumn{2}{|c|}{ Cakupan KBLI } & Definisi \\
\hline Kuliner & $\begin{array}{l}495 \text { unit } \\
(36,21 \%)\end{array}$ & $\begin{array}{l}10792, \\
10790, \\
10793, \\
10733,\end{array}$ & $\begin{array}{l}10794, \\
10799 . \\
10710, \\
10750\end{array}$ & $\begin{array}{l}\text { Kegiatan persiapan, pengolahan, } \\
\text { penyajian produk makanan dan } \\
\text { minuman yang menjadikan unsur } \\
\text { kreativitas, estetika, tradisi, dan/atau } \\
\text { kearifan lokal; sebagai elemen } \\
\text { terpenting dalam meningkatkan cita } \\
\text { rasa dan nilai produk tersebut, untuk } \\
\text { menarik daya beli dan memberikan } \\
\text { pengalaman bagi konsumen. }\end{array}$ \\
\hline $\begin{array}{l}\text { Kriya } \\
547 \text { unit }\end{array}$ & $\begin{array}{l}547 \text { unit } \\
(40,01 \%)\end{array}$ & $\begin{array}{l}16291, \\
31001, \\
32111, \\
32202, \\
32112, \\
13912, \\
13922, \\
13924, \\
16291, \\
16293, \\
13912, \\
32401, \\
23951, \\
17022, \\
23932,\end{array}$ & $\begin{array}{l}16292, \\
31004, \\
32120, \\
32402, \\
32909, \\
13921, \\
13923, \\
16292, \\
16292, \\
16299, \\
13921, \\
23963, \\
13122, \\
23959,\end{array}$ & $\begin{array}{l}\text { Bagian dari seni rupa terapan yang } \\
\text { merupakan titik temu antara seni dan } \\
\text { desain yang bersumber dari warisan } \\
\text { tradisi atau ide kontemporer yang } \\
\text { hasilnya dapat berupa karya seni, } \\
\text { produk fungsional, benda hias dan } \\
\text { dekoratif, serta dapat dikelompokkan } \\
\text { berdasarkan material dan eksplorasi } \\
\text { alat teknik yang digunakan, dan juga } \\
\text { tematik produknya }\end{array}$ \\
\hline
\end{tabular}




$\begin{array}{lllll}\text { Fashion } & 325 \text { unit } & 14111, & 14120, & \text { Suatu gaya } \\ & (23,77 \%) & 14131, & 14302, & \text { berpenampilan yang mencerminkan } \\ & & 15121, & 15201 & \text { diri dan identitas kelompok }\end{array}$

Sumber: data SIMK diolah, 2014

Keberdaan industri kreatif di Sumatera Barat tersebar hampir diseluruh kabupaten dan kota namun penyebarannya cenderung tidak merata. Populasi industri kriya terbesar berada di Kabupaten Agam, sedangkan populasi industri kuliner terbesar terdapat di Kabupaten Sawahlunto dan populasi industri fashion terbesar berada di Kabupaten Agam. Dari 19 kabupaten/kota yang terdapat di Sumatera Barat, hanya 18 kabupaten/kota yang memiliki industri kreatif, terdapat 1 kabupaten yakni Kepulauan Mentawai yang tidak memiliki industri kreatif. Populasi industri kreatif terbesar ditemukan di Kabupaten Agam dengan jumlah 299 perusahaan (21,87\%), sedangkan yang paling sedikit ditemukan di Kabupaten Solok Selatan dengan jumlah 2 perusahaan (0,15\%)

Analisis deskriptif dilakukan guna memberikan gambaran tentang variabel penelitian. Hasil statistik deskriptif dari variabel yang diamati menunjukkan bahwa 78, 42\% pengusaha industri kreatif adalah wanita. Sebesar 92, 69\% mereka tidak pernah mendapatkan pelatihan, belum pernah menjalin kemitraan (91, 22\%) dan belum tergabung dalam asosiasi usaha (90,71\%). Sebesar 93, 86\%nya beskala industri mikro dan tidak memiliki status hukum yang jelas $(98,46 \%)$. Dilihat dari kegiatan utamanya, industri kreatif terbesar adalah sektor kriya yakni $40.01 \%$. Dari sisi lokasi keberadaannya, $62.11 \%$ berada di pedesaan dan 37, 89\% nya berada di perkotaan. Hal ini kontras dengan situasi di negara maju dimana menurut Fahmi, Koster dan Dijk (2016) sebanyak 71, 2\% industri kreatifnya justru berada di perkotaan.

Pengusaha industri kreatif tertua berada pada umur 88 tahun dan persentase terbesar pendidikan pengusaha berada pada tingkatan SLTA yakni 32.63\%. Dilihat dari pengalaman perusahaan, perusahaan tertua sudah beroperasi selama 73 tahun. Berdasarkan analisis data diketahui bahwa potensi pertumbuhan industri kreatif di Sumatera Barat sangat besar hal ini terlihat dari persentase startup industri (perusahaan yang telah beroperasi kurang dari 10 tahun) yang mencapai $46.16 \%$. Tingginya persentase kemunculan star-up industry menunjukkan geliat pertubuhan industri kreatif di Sumatera Barat. Kondisi ini sejalan dengan karaktersitik umum industri kreatif di Sumatera Barat dimana start-up industry cenderung masih belum berbadan hukum, berskala mikro, serta lemahnya networking/ relasi bisnis.

Tabel 3. Statistik Deskriptif Karakterisitk Wilayah Sumatera Barat

\begin{tabular}{lllccc}
\hline Variabel & $\mathbf{N}$ & Minimum & Maksimum & Rata-rata & Standar deviasi \\
\hline GDP & 1.367 & 20,412 & 46,774 & 33,425 & 8384,14 \\
HDI & 1.367 & 63,33 & 79,83 & 70,925 & 4,647 \\
GINI & 1.367 & 0,24 & 0,37 & 0,29 & 0,39 \\
NET & 1.367 & 4,02 & 33,09 & 17,346 & 8,615 \\
\hline
\end{tabular}

Variabel dependen (inklusi sosial) diukur dari serapan tenaga kerja wanita pada industri kreatif, sedangkan variabel indipenden dilihat berdasarkan karakteristik usaha, karakteristik pengusaha dan karakteristik wilayah. Hasil analisis regresi berganda untuk faktor-faktor yang mempengaruhi inklusi sosial industri kreatif di Sumatera Barat dapat dilihat pada tabel 4. Nilai Adj R-squared sebesar 0.6658 menunjukkan bahwa kemampuan 
variabel bebas dalam menjelaskan keragaman variabel respon adalah sebesar 66,58\% sedangkan sisanya $33,42 \%$ lagi dijelaskan oleh variabel lain diluar model. Nilai konstanta negative (-0.2519821) dapat diartikan bahwa rata-rata kontribusi variabel lain diluar model memberikan dampak negative terhadap nilai SI. Hasil analisis regresi berganda dengan menggunakan STATA menunjukkan bahwa karakteristik pengusaha (gender dan partnership), karakteristik usaha (asset dan sub sektor) serta karakteristik wilayah (GDP/capita) memiliki pengaruh dan signifikan secara statistik terhadap serapan tenaga kerja wanita pada industi kreatif di Sumatera Barat.

Tabel 4. Hasil Analisis Regresi Berganda

\begin{tabular}{lllll}
\hline \multicolumn{1}{c}{ Variabel } & \multicolumn{1}{c}{ Koefisien } & Std. Err & \multicolumn{1}{c}{ t } & P>t \\
\hline a & $-0,2519821$ & 0,4438284 & $-0,57$ & 0,570 \\
EDU & 0,0007769 & 0,0020482 & 0,38 & 0,705 \\
GENDER & $0,6803557 * * * *$ & 0,015091 & 45,08 & 0,000 \\
AGE & $-0,0007743$ & 0,0008364 & $-0,93$ & 0,355 \\
SKILL & $-0,004745$ & 0,0216975 & $-0,22$ & 0,827 \\
COLL & $-0,0344651^{*}$ & 0,0195081 & $-1,77$ & 0,078 \\
NETWORK & 0,0082856 & 0,0190066 & 0,44 & 0,663 \\
HIGH EDU & $-0,0325041$ & 0,033449 & $-0,97$ & 0,331 \\
PRODUCTIVE & $-0,0189569$ & 0,0199544 & $-0,95$ & 0,342 \\
SECTOR & & & & \\
KRIYA & $-0,0353129 * *$ & 0,0155363 & $-2,27$ & 0,023 \\
FASHION & $-0,0402618^{* *}$ & 0,016167 & $-2,49$ & 0,013 \\
BEX & 0,0006744 & 0,0006322 & 1,07 & 0,286 \\
SIZE & 0,014129 & 0,0229631 & 0,62 & 0,538 \\
LEGAL & $-0,0019114$ & 0,0443114 & $-0,04$ & 0,966 \\
EXSPORT & $-0,1094598$ & 0,0781226 & $-1,40$ & 0,161 \\
ASET & $0,0097251^{* * *}$ & 0,0040084 & 2,43 & 0,015 \\
LOC & $-0,0542796$ & 0,0373892 & $-1,45$ & 0,147 \\
GDP & $4,08 \mathrm{e}-06 *$ & $2,08 \mathrm{e}-06$ & 1,96 & 0,051 \\
GINI & $-0,2748285$ & 0,4183999 & $-0,66$ & 0,511 \\
HDI & 0,0069637 & 0,0076891 & 0,91 & 0,365 \\
NET & $-0,0063498$ & 0,0046731 & $-1,36$ & 0,174 \\
Number of observations & 1367 & & Prob > F & 0,0000 \\
R-squared & 0,6707 & Adj R-squared & 0,6658 \\
F(20, 1346) & 137,05 & Root MSE &, 1982 \\
\hline$\quad * * *$ dan * signifikansi pada taraf nyata $1 \%, 5 \%$ dan & $10 \%$ & \\
& & &
\end{tabular}

Karakterstik pengusaha yang mempengaruhi inklusi sosial industri kreatif adalah gender dan collaboration. Gender berpengaruh signifikan secara statistik dimana pengaruhnya bersifat positif. Dari persamaan model didapatkan bahwa pengusahanya wanita memiliki inklusi sosial $0.680355 \mathrm{x}$ lebih tinggi dibandingkan pengusaha laki-laki dengan asumsi variabel indipenden lainnya bernilai tetap. Disisi lain variabel collaboration berpengaruh signifikan secara statistik tetapi pengaruhnya bersifat negatif. Dari persamaan model regresi yang dihasilkan industri yang melakukan kolaborsi dengan mitra/pihak lain memiliki serapan tenaga kerja wanita $0.34465 x$ lebih rendah dibandingkan industri yang tidak menjalin mitra dengan pihak manapun. Menurut hasil penelitian Maksimov et al (2017) tentang peran industi mikro kecil dalam pengentasan kemiskinan di tujuh negara berkembang di dunia ternyata female ownership lebih mahir dalam melakukan eksploitasi 
local business dan sociental relationships termasuk dalam hal pengadaan tenaga kerja untuk bisnisnya. Sedangkan industri yang bermitra dengan pemerintah atau instansi lain lebih effisien dalam bertransaksi dengan konstituen lain di lingkungan bisnis serta memiliki kemampuan ekspor yang lebih tinggi. Kemampuan berkolaborasi yang tinggi dapat mendorong perusahaan untuk meningkatkan pemanfaatan tekhnologi dan peningkatan efisiensi khususnya dalam penggunaan tenaga kerja.

Karakteristik usaha yang mempengaruhi inklusi sosial industri kreatif adalah asset dan sub sektor. Hasil analisis regresi menunjukkan bahwa pada saat variabel indipenden lainnya bernilai tetap, peningkatan setiap unit asset dapat meningkatkan serapan tenaga kerja wanita. Hal ini disebabkan karena perluasan asset terjadi karena perluasan skala usaha yang juga membutuhkan peningkatan jumlah tenaga kerja untuk kegiatan operasional industri. Menurut hasil penelitian Fahmi et al (2016) bahwa industri kreatif di Indonesia memiliki karakteristik yang berbeda dengan di negara maju. Industri kreatif di Indonesia sebagaian besar bersifat "craftbased" dan seringkali tidak terkait dengan kekayaan intelektual dan inovasi. Levickaite (2015) menyebutkan bahwa industri kreatif yang mempromosikan long-established traditional businesses embedded yang banyak dijumpai di negara berkembang sebagai cultural creative industry. Proses produksi pada industri kreatif yang berbasis nilai-nilai kultural seperti kriya, kuliner dan fashion memiliki karakter pengerjaan yang manual, membutuhkan kehati-hatian yang tinggi dan bersifat done by hand. Karakter pengerjaan yang demikian sangat identik dengan skill yang dimiliki oleh tenagakerja wanita. Dengan demikian untuk subsector tersebut kebutuhan tenaga kerja wanita lebih besar dibandingkan sub sektor kreatif lainnya yang tidak bersifat "handwork".

Karakteristik wilayah yang mempengaruhi inklusi sosial industri kreatif adalah GDP/capita dimana pengaruhnya bernilai positif. Ini menandakan bahwa semakin makmur tingkat kesejahteraan suatu wilayah maka semakin besar pula tingkat partisipasi masyarakatnya dalam pasar tenaga kerja termasuk tenaga kerja wanita. Hal ini sejalan dengan hasil penelitian Clare (2013) dan Orcao at al (2018) bahwa masyarakat yang tinggal didaerah relatif maju, memiliki infrastruktur yang memadai serta lifestyle dan quality of life yang baik dapat mendorong terwujudnya inklusi sosial.

\section{Simpulan}

Berdasarkan hasil dan pembahasan, dapat disimpulkan bahwa industri kreatif di Sumatera Barat didominasi oleh tiga sub sektor utama yakni kriya, kuliner dan fashion. Keberadaan industri kreatif dinilai penting terutama dalam mewujudkan inklusi sosial yang diukur dari penyerapan tenaga kerja wanita. Rata-rata rasio serapan tenaga kerja wanita pada industrti kreatif mencapai $78,4342 \%$. Industri ini juga memiliki potensi pertumbuhan yang sangat besar, hal ini terlihat dari pertumbuhan startup usaha di tahun 2014 yang mencapai $46.16 \%$. Karakteristik pengusaha (gender dan partnership), karakteristik usaha (asset dan sub sektor) serta karakteristik wilayah (GDP/capita) memiliki pengaruh dan signifikan secara statistik terhadap pencapaian inklusi sosial yang diukur berdasarkan serapan tenaga kerja wanita pada industi kreatif di Sumatera Barat.

Berdasarkan hasil penelitian, maka disarankan upaya untuk merwujudan inklusi sosial melalui penguatan industri kreatif dalam menyerap tenaga kerja wanita dapat mempertimbangkan karakteristik kewirausahaan, karakteristik usaha dan karakteristik 
wilayah. Peningkatan inklusi social dari sisi karakteristik kewirausahaan dapat dilakukan melalui upaya pemberdayaan pengusaha wanita dan mendorong hubungan kerjasama atau kolaborasi antara industri kreatif dengan instansi atau lembaga lainnya. Peningkatan inklusi sosial dari sisi karakteristik usaha dapat dilakukan melalui upaya penguatan asset usaha dan pengembangan sub sektor kuliner, kriya dan fashion. Peningkatan inklusi sosial dari sisi karakteristik wilayah dapat dilakukan melalui upaya penyediaan infrastruktur wilayah yang kondusif.

\section{Daftar Pustaka}

Chaerayi. S dan Jose, J., P. 2016. Empowerment and Social Inclusion of Muslim Women: Towards a New Conceptual Model. Jurnal of Rural Studies, 45, 243-251.

Clare. K. 2013. The Essential Role of Place within the Creative Industries: Boundaries, Networks and Play. Cities, 34, 52-57.

Cunningham, S.D. 2002. From Cultural to Creative Industries: Theory, Industry and Policy Implications. Media International Australia Incorporating Culture and Policy: Quarterly Journal of Media Research and Resources, 102 (1), 54-65.

Dasaluti, T. 2009. Analisis Pengembangan Usaha Mikro dalam Mendukung Pemberdayaan Perempuan di Pulau Kecil (Studi Kasus di Pulau Bunaken, Kota Manado, Sulawesi Utara). Tesis. Institut Pertanian Bogor

Davys. D., Tickle, E.J, 2008. Social Inclusion and Valued Roles: A Supportive Framework. International Journal of Therapy and Rehabilitation. 15, 2-7.

Fahmi, F.Z., Koster, S., Dijk, J.V, 2016. The Location of Creative Industries in a Developing Country: The Case of Indonesia. Cities, 59, 66-79.

Fahmi, F.Z., McCann, P, Koster, S, 2017. Creative Economy Policy in Developing Countries: The Case of Indonesia, Urban Studies, 54 (6), 1367-1384.

Fletschner, D., Carter, M.R, 2008, Constructing and reconstructing gender: reference group effects and women's demand for entrepreneurial capital. The journal of socio-economics, $37(2), 672-693$

Flew, T, 2013, Global creative industries. Wiley, United States.

Granger, R.C., Hamilton, C, 2010, Re-Spatializing: The Creative Industries: a Relational Examination of Underground Scenes, and Professional and Organizational Lock-in, Creative Industries Journal, 3(1), 47-60.

Handy, F, Kassam, M, 2006, Practice what you preach? The Role of Rural NGOs in Womens's Empowerment. Journal of community practice. 14, 69-91. 
Haslindah, 2011, Analisis Penyerapan Tenaga Kerja Wanita dan Produktifitas Pada Pengolahan Pascapanen Sektor Pertanian di Kabupaten Pinrang, ILTEK, 6 (12), 850854.

Henderson G.R., Williams, J.D, 2013, From Exclusion to Inclusion: An Introduction to the Special Issue on Marketplace Diversity and Inclusion. Journal of public and marketing, 32 (special issue), 1-5.

Howkins, J. 2001. The Creative Economy: How people make money from ideas, Allen Lane, The Penguin Press.

Levickaite, R. 2015. Modelling of the Creative Economy Sustainable Development. Vilnius Gediminas Technical University, Dissertation.

Maksimov, V., Wang, S.L., Luo, Y, 2017, Reducing Poverty in the Least Developed Countries: The Role of Small and Medium Enterprises, Journal of World Business, 52, 244-257

Orcao, E., Perez, S., Garcia, S.V, 2018, Location Conditions for the Clustering of Creative Activities in Extra-Metropolitan Areas: Analysis and Evidence from Spain, Applied Geography. 91, 1-9.

Phuangrod, K., Lerkiatbundit, S., Aujiraponpan, S, 2017. Factor Affecting Innovativeness of Small and Medium Enterprises in the Five Southern Border Provinces. Kasetsart Journal of Social Sciences, 38, 204-211.

Pierson, J, 2010. Tackling Social Exclusion, Routledge, London

Simatupang, T.M. Yudoko, G., Handayati, Y., Pascasuseni, A., Permadi, K., Listiani. W. 2008. Analisis Kebijakan Pengembangan Industri Kreatif di Kota Bandung. Jurnal Manajemen Teknologi V, 8 (1).

Sudarwati, W., Prasetyawati, M. 2015. Model Pengembangan Industri Kreatif Pemula Untuk Meningkatkan Daya Saing Melalui Analisis SWOT dan Kanvas Strategy, https://jurnal.ftumj.ac.id/index.php/semnastek.

Sumantri, B, 2013, Pengaruh Jiwa Kewiarusahaan Terhadap Kinerja Usaha Wirausaha Wanita Pada Industri Pangan Rumahan di Bogor. Tesis. Institut Pertanian Bogor

Sung, T.K, 2015, Application of Irformation Technology in Creative Economy: Manufacturing vs Creative Industries, Technological Forecasting and Social Change, 96, 111-120

Widiastiti, A., Astra, I., Arsana, I, 2012, Resistensi Perempuan Bali Pada Sektor Industri Kreatif di Desa Paksebali, Kecamatan Dawan, Kabupaten Klungkung. E-Jurnal Kajian Budaya Universitas Udayana, 1 (1). 